\title{
PROFITABILITY DETERMINANTS OF INSURANCE MARKETS IN SELECTED CENTRAL AND EASTERN EUROPEAN COUNTRIES
}

\author{
TOMISLAVA PAVIC KRAMARIC, MARKO MILETIC, IVAN PAVIC
}

\begin{abstract}
:
This paper analyses the influence of insurance company-specific, insurance industry-specific and macroeconomic variables on performance of insurance markets in selected Central and Eastern European countries. Specifically, the research covers insurance industry in Croatia, Slovenia, Hungary and Poland in the period 2010 - 2014. Two performance variables were employed in the model, i.e. return on assets (ROA) and return on equity (ROE) while explanatory variables comprise of size measured on the basis of gross written premium, type dummy variable indicating life, non-life or composite insurance company, share of premium ceded to reinsurance, combined ratio, ownership variable indicating foreign or domestic ownership, age, organizational form dummy variable referring to joint stock companies or mutual and real GDP per capita growth. Employing static panel model results of the analysis reveal that variable age positively and significantly affect performance when measured with both ROA and ROE. Moreover, another variable that significantly influences performance in terms of ROE is real GDP per capita growth taking a positive sign.
\end{abstract}

\section{Keywords:}

insurance companies, firm performance, international financial markets, panel data models

JEL Classification: C23, G22, L25

\section{Authors:}

TOMISLAVA PAVIC KRAMARIC, University of Split, University Department of Professional Studies, Croatia, Email: tpavic@oss.unist.hr MARKO MILETIC, University of Split, University Department of Professional Studies, Croatia, Email: mamiletic@oss.unist.hr

IVAN PAVIC, University of Split - Faculty of Economics, Croatia, Email: pavic@efst.hr

\section{Citation:}

TOMISLAVA PAVIC KRAMARIC, MARKO MILETIC, IVAN PAVIC (2017). Profitability Determinants of Insurance Markets in Selected Central and Eastern European Countries. International Journal of Economic Sciences, Vol. VI(2), pp. 100-123., 10.20472/ES.2017.6.2.006 


\section{Introduction}

The nature of insurance activity comprises covering risks for the economy, financial and corporate undertakings and households. Unlike most financial products, it is characterised by the reversal of the production cycle insofar as premiums are collected when the contract is entered into and claims arise only if a specified event occurs. Insurers intermediate risks directly managing them through diversification and risk pooling enhanced by a range of other techniques (IAIS, Insurance Core Principles, 2015). Therefore, their main business is insuring against risks for a profit.

Favourable financial performance is a prerequisite for efficient, fair, safe and stable insurance markets for the benefit and protection of policyholders. Moreover, as stated by Burca and Batrînca (2014), profit attracts investors and improves the level of solvency, and thus, strengthens consumers' confidence. Furthermore, profit plays an essential role in persuading policyholders and shareholders to supply funds into insurance firms. Thus, one of the objectives of management of insurance companies is to attain profit as an underlying requirement for conducting any insurance business (Lee, 2014).

The financial performance of insurance companies is also relevant within the macroeconomic context since insurance companies have important functions and contribute to the development of the economic and financial system. The fact that it is becoming increasingly important financial system's component is shown through the share of assets of insurance companies in total assets of all financial institutions which in 2014 in Croatia accounted for 6.84\% (Croatian Insurance Bureau, Insurance Market in the Republic of Croatia, 2015).

Investigation of determinants of corporate performance has received much attention of the economists. In the beginning, such papers encompassed developed countries only focusing mainly on banking sector. Over the time, a number of papers dealing with insurance companies' profitability in emerging markets, has been produced e.g. Kozak (2011), Burca and Batrînca (2014) and Öner Kaya (2015) to name a few. However, there is still no consensus on what insurance companies' profitability determinants are. Hence, the contribution of our paper is multifold. First, we have employed two dependent variables as a proxy for financial performance, ROA and ROE, to make the results more robust. Second, the paper covers the plethora of different variables including firm specific, industry specific as well as macroeconomic variables. Finally, since all previous papers dealt with insurance companies' profitability at a national level, the most important feature of this paper is the cross-country level of the analysis of the issue investigated. Specifically, our analysis covers insurance markets of Croatia, Slovenia, Hungary and Poland. Therefore, this is, according to our knowledge, the first study of its kind ever conducted for the insurance markets.

The analysis covers the period 2010-2014, while the research is conducted employing static panel model using STATA version 11.0. 
The rest of the paper is structured as follows. After the Introduction, overview of the insurance markets in selected countries covered by the analysis follows. The section 3 provides findings of the previous research dealing with determinants of insurance companies' profitability. Description of variables is given in section 4 while data sources and sample construction follow in the fifth part. Econometric specification is given in section 6. Finally, the empirical findings, given in section 7, are compared with the existing literature and lead to conclusions.

\section{Overview of the Insurance Markets}

Our sample consists of South-Eastern post transition European countries including Croatia, Slovenia, Hungary and Poland. Besides data availability, the main reason why these countries were chosen for the analysis lies in the fact that they shared a similar historical and political background as well as economic development path. Financial system' framework with insurance markets of these countries was also very similar by the degree of their development, structure and potential.

Specifically, until the beginning of 1990ies the financial systems of these countries consisted only of the banks, acting under non-market rules, with all significant parameters determined by the government. Demand for financial services, formulated by the households and enterprises were limited rather to traditional loans. There were no other types of financial intermediation besides only one, state-owned, insurance company. In Croatia that was Croatia osiguranje, in Slovenia Zavarovalnica Triglav, in Hungary Hungaria and in Poland PZU.

After 1990ies these countries, among others, entered changes thorough institutional and economic reforms. Their financial sectors have been the subject of a deep restructuring, privatisation and consolidation. New insurance companies have entered the markets, range of insurance products offered has increased as well as share of foreign ownership. As a consequence, a significant growth in the assets of insurance companies has been observed. The above mentioned insurance companies which were present in the market have monopolistic position were privatised in the meantime, with the exception of Zavarovalnica Triglav (FESSUD, Studies in Financial Systems No. 7, Financial System in Poland, 2013; Tipuric, Pejic Bach and Pavic, 2008). Though, these companies retained their leading position. Specifically, in 2014 Croatia osiguranje in Croatia has $27.4 \%$ market share while Zavarovalnica Triglav has $31.3 \%$ share in total Slovenian insurance market. Allianz Hungária Biztosító Zrt. accounts for $14.8 \%$ of Hungarian insurance market while PZU's (both PZU life and nonlife) share amounts to 29.9 \% (Croatian Financial Services Supervisory Agency, Statistics 2014; Slovenian Insurance Supervision Agency, Annual Report 2014; Magyar Nemzeti Bank, Polish Financial Supervision Agency, Annual bulletin. Insurance market 2014).

The international comparability and significance of an insurance industry are commonly measured through three key indicators:

- gross insurance premium share in the gross domestic product and

- gross insurance premium per inhabitant. 
According to these indicators, shown in Table 1, countries selected for this analysis have lower shares of premium in GDP as well as annual investments in insurance per inhabitant in relation to EU average. Croatia and Hungary are lacking the most, while Slovenian insurance market stands out for significantly better better indicators of level of development.

Table 1 Comparative analysis of key insurance development indicators in 20102014

\begin{tabular}{|c|c|c|c|c|c|c|c|c|c|c|}
\hline & \multicolumn{2}{|c|}{ Croatia } & \multicolumn{2}{|c|}{ Slovenia } & \multicolumn{2}{|c|}{ Hungary } & \multicolumn{2}{|c|}{ Poland } & \multicolumn{2}{|c|}{ EU average* } \\
\hline & $\begin{array}{l}\text { GWP } \\
\text { per } \\
\text { capita }\end{array}$ & $\begin{array}{l}\text { Share } \\
\text { of } \\
\text { GWP } \\
\text { in } \\
\text { GDP }\end{array}$ & $\begin{array}{l}\text { GWP } \\
\text { per } \\
\text { capita }\end{array}$ & $\begin{array}{l}\text { Share } \\
\text { of } \\
\text { GWP } \\
\text { in } \\
\text { GDP }\end{array}$ & $\begin{array}{l}\text { GWP } \\
\text { per } \\
\text { capita }\end{array}$ & $\begin{array}{l}\text { Share } \\
\text { of } \\
\text { GWP } \\
\text { in } \\
\text { GDP }\end{array}$ & $\begin{array}{l}\text { GWP } \\
\text { per } \\
\text { capita }\end{array}$ & $\begin{array}{l}\text { Share } \\
\text { of } \\
\text { GWP } \\
\text { in } \\
\text { GDP }\end{array}$ & $\begin{array}{l}\text { GWP } \\
\text { per } \\
\text { capita }\end{array}$ & $\begin{array}{l}\text { Share } \\
\text { of } \\
\text { GWP } \\
\text { in } \\
\text { GDP }\end{array}$ \\
\hline 2010 & 281 & $2.8 \%$ & 1.023 & $5.8 \%$ & 267 & $3.1 \%$ & 334 & 3.7 & 1.950 & $8.0 \%$ \\
\hline 2011 & 279 & $2.7 \%$ & 987 & $5.5 \%$ & 259 & $2.9 \%$ & 349 & 3.6 & 1.889 & $7.5 \%$ \\
\hline 2012 & 277 & $2.7 \%$ & 982 & $5.6 \%$ & 245 & $2.7 \%$ & 382 & 3.8 & 1.877 & $7.4 \%$ \\
\hline 2013 & 279 & $2.8 \%$ & 941 & $5.4 \%$ & 259 & $2.7 \%$ & 352 & 3.5 & 1.922 & $7.5 \%$ \\
\hline 2014 & 264 & $2.6 \%$ & 920 & $5.1 \%$ & 272 & $2.6 \%$ & 335 & 3.2 & 1.993 & $7.6 \%$ \\
\hline
\end{tabular}

Source: Insurance Europe, European insurance industry database, https://www.insuranceeurope.eu/insurancedata [April $3^{\text {rd }}$ 2017]

${ }^{*} E U$ average data was provided by Insurance Europe's members, i.e. the members of the European Union (except Lithuania), but including Switzerland, Iceland, Norway, Liechtenstein and Turkey.

In terms of profitability, however, the situation is different. As shown by Figures 1 and 2, profitability of Polish insurance industry in terms of ROA and ROE achieved significantly higher rates than the other selected countries covered by this analysis. ROA in Slovenia ranged between $1.43 \%$ and $2.03 \%$, while in Hungary ROA rates ranged between $0.08 \%$ and $1.67 \%$ in the period 2010 - 2014. Croatian insurance industry has registered similarly low ROA rates while it is the only country that achieved negative ROA in 2014. 
Figure 1 Profitability (ROA) of insurance industry in selected countries in 20102014

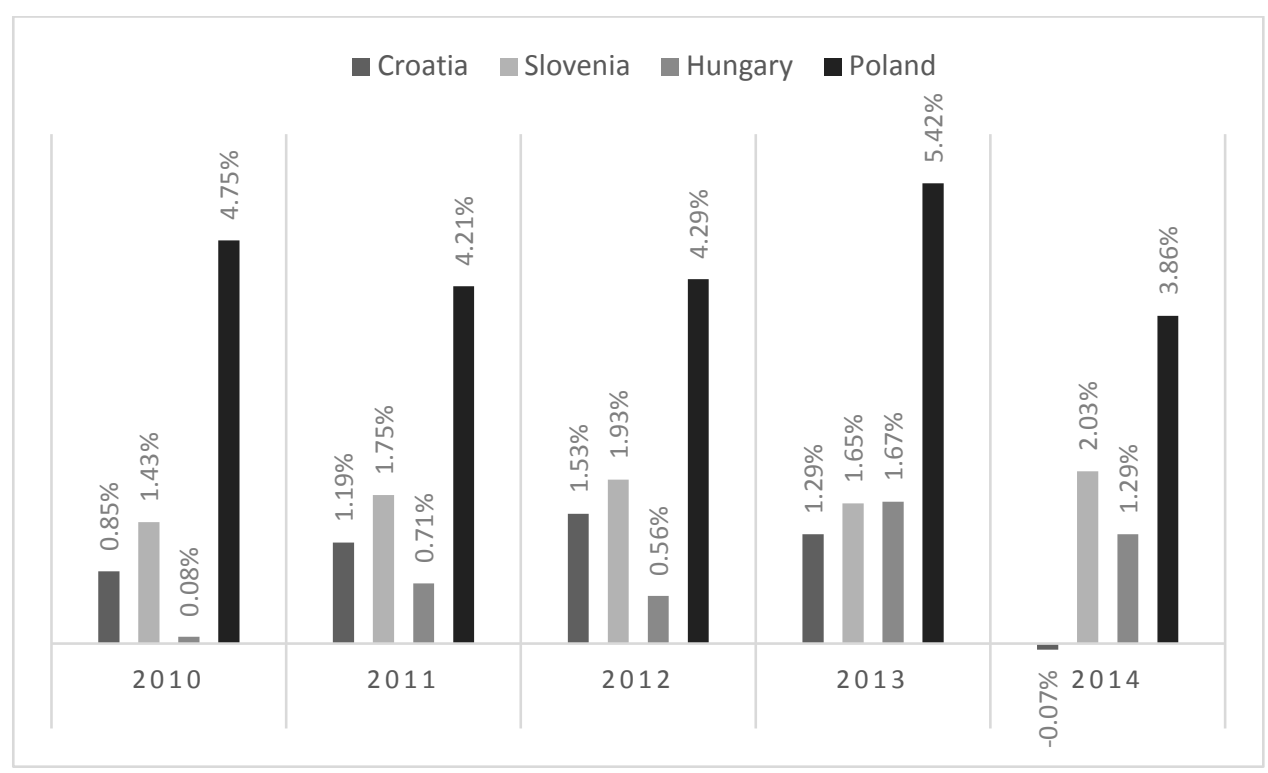

Source: authors' calculation based on data from: Croatia: Croatian Financial Services Supervisory Agency, Statistics, http://www.hanfa.hr/publications/statistics/; Slovenia: Insurance Supervision Agency, Annual Reports, 2010-2014 issues, https://www.a-zn.si/o-agenciji/letna-porocila/; Hungary: Magyar Nemzeti Bank, Golden Books, https://www.mnb.hu/en/supervision/time-series/golden-books; Poland: Polish Financial Supervision Agency, Annual bulletin, Insurance market, Aggregated efficiency ratios, 2010-2014 issues,

https://www.knf.gov.pl/en/about the market/Insurance/Financial and statistical data/Annual data/ann ual.html

Profitability in terms of ROE in Slovenia ranged between $8.78 \%$ and $9.99 \%$ whereas in Hungary this range is much larger, i.e. it ranged between $0.75 \%$ and $14.65 \%$. Croatia registered somewhat lower ROE rates which was negative in 2014. 
Figure 2 Profitability (ROE) of insurance industry in selected countries in 20102014

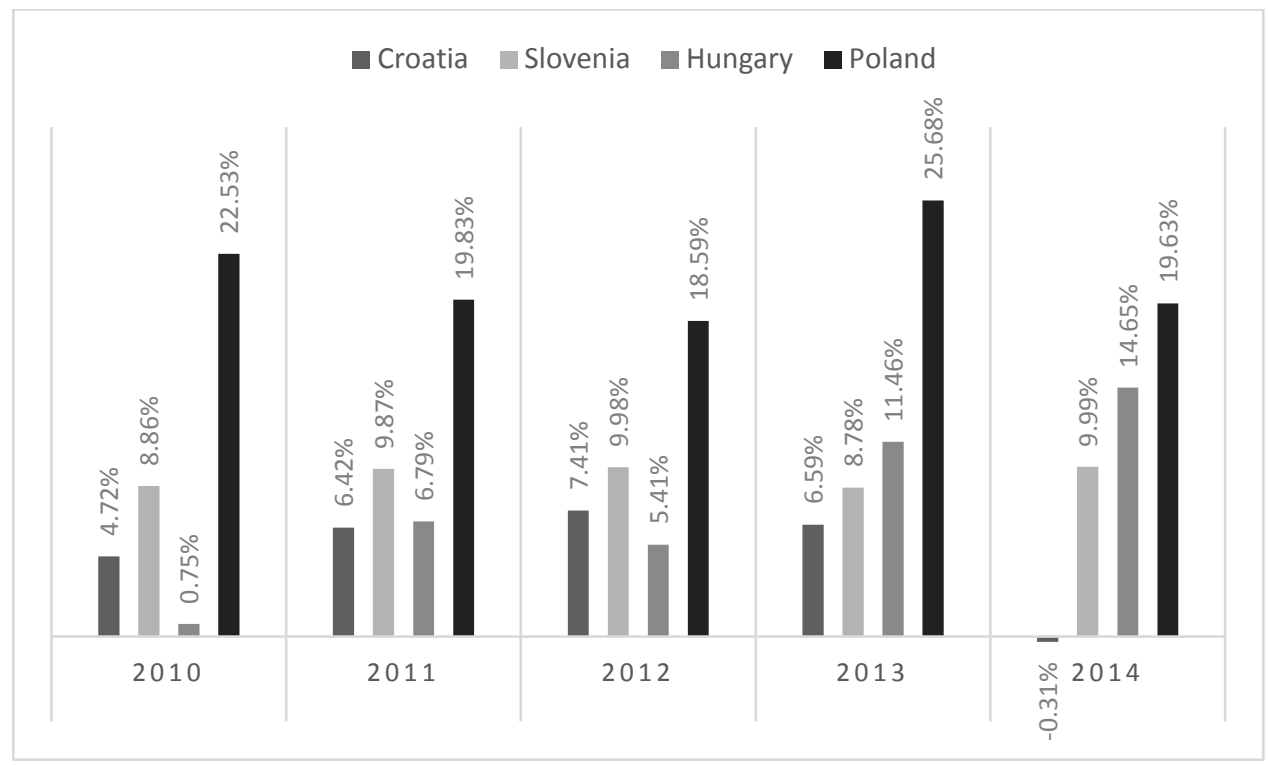

Source: authors' calculation based on data from: Croatia: Croatian Financial Services Supervisory Agency, Statistics, http://www.hanfa.hr/publications/statistics/; Slovenia: Insurance Supervision Agency, Annual Reports, 2010-2014 issues, https://www.a-zn.si/o-agenciij/letna-porocila/; Hungary: Magyar Nemzeti Bank, Golden Books, https://www.mnb.hu/en/supervision/time-series/golden-books; Poland: Polish Financial Supervision Agency, Annual bulletin, Insurance market, Aggregated efficiency ratios, 2010-2014 issues,

https://www.knf.gov.pl/en/about the market/Insurance/Financial and statistical data/Annual data/ann ual.html

Despite the fact that Croatian insurance market achieved negative profitability rates in 2014, insurance markets in general in all countries performed well. This is important since insurers' profitability has direct implications on policyholders, shareholders, potential investors, employees, and other interested parties (Öner Kaya, 2015).

\section{Literature Review}

Due to the growing interest of scientists in the field of determinants of profitability in the insurance industry the number of such papers is increasing. However, since it was not possible to find papers that deal with cross-country analysis of the determinants of profitability in the insurance sector, attention will be focused on a smaller number of papers dealing with this issue at national level.

Kozak (2011) studied determinants of profitability of non-life insurance companies in Poland during integration with the European financial system using a panel of 25 nonlife insurance companies for the period of 2002-2009. The results of a regression model that was estimated indicate that the reduction in the share of motor insurance in the portfolio, with simultaneous increase of other types of insurance, has a positive impact on profitability and cost-efficiency of insurance companies. However, offering too broad spectrum of classes of insurance negatively impacts its profitability and cost efficiency. 
Companies improve profitability and cost efficiency with an increase of their gross premiums and decrease of total operating expenses. Additionally, GDP growth and the market share of foreign owned companies positively impact profitability of non-life insurance companies during the integration period.

Öner Kaya (2015) examined the effects of firm-specific factors on the profitability of nonlife insurance companies in Turkey. The analysis was done on a sample of 24 non-life insurance companies operating in the period 2006-2013 with profitability being measured with two different variables: technical profitability ratio and sales profitability ratio. Eight independent variables were tested in the study including size of the company, age of the company, loss ratio, insurance leverage ratio, current ratio, premium growth rate, motor insurance and premium retention ratio. The ordinary least squares (OLS) regression model, the one-way fixed effects model, and the one-way random effects model were employed in this study for the analysis of panel data According to the empirical results, the firm-specific factors affecting the profitability of Turkish non-life insurance companies are the size of the company, age of the company, loss ratio, current ratio, and premium growth rate. Specifically size and premium growth rate have positive effect on the performance, whereas all other variables significantly influencing performance have negative sign. This holds for both dependent variables.

Burca and Batrînca (2014) analysed the determinants of financial performance in the Romanian insurance market on the sample of 21 insurance companies during the period 2008-2012. Return on assets was employed in the model as the dependent variable while 13 explanatory variables (including firm-specific, industry-specific and macroeconomic variables) were tested using the multiple regression analysis. According to the findings, the determinants of the financial performance in the Romanian insurance market are leverage, size, gross written premium growth, underwriting risk, risk retention ratio and solvency margin.

Lee (2014) investigated the effects of firm-specific and macroeconomic factors on profitability of property-liability insurance industry in Taiwan. Using the panel data of 15 insurers over the 1999 through 2009 time period two dependent variables were employed in the model including operating ratio and return on assets to measure insurers' profitability. The author employed ordinary least square (OLS) regression model, fixed effect model (FEM) and random effect model (REM) for the analysis while the results show that underwriting risk, reinsurance usage, input cost, return on investment (ROI) and financial holding group have significant influence on profitability in both operating ratio and ROA models.

There is also a great body of literature dealing with determinants of insurance companies profitability in developed countries. For example, Doumpos, Gaganis and Pasiouras (2012) have analysed performance of insurance companies from 91 countries in the period 2005-2009. Employ the preference ranking organization method for enrichment evaluations (PROMETHEE) II method, the authors employ seven financial performance variables such as equity to assets ratio, solvency ratio, technical reserves ratio, liquidity, $\mathrm{ROA}$ etc., while determinants of performance include size, share 
of reinsurance, real GDP growth to name a few. Shiu (2004) has conducted an analysis on the sample of UK general insurance companies over the period 1986 to 1999. Using an ordinary least squares regression model, this paper finds that liquidity, unexpected inflation, interest rate level and underwriting profits are statistically significant determinants of the performance of U.K. general insurers.

Many of the papers relating to developed markets analysed performance in terms of efficiency. For example, Cummins, Weiss and $\mathrm{Zi}$ (1999) have analysed the efficiency of U.S. mutual and stock property-liability insurers using frontier analysis while Cummins and Rubio-Misas (2001) on the sample of Spanish firms have used frontier efficiency analysis to estimate cost, technical, and allocative efficiency, as well as using Malmquist analysis to measure total factor productivity (TFP) change. Fecher et al. (1993) investigated the relative productive performance or technical efficiency of French insurance companies. The analysis refers to the period $1984-1989$ and it is conducted using parametric and non-parametric approaches. As explanatory variables, various key characteristics of insurance companies were used such as the reinsurance ratio, the distribution ratio, the legal status, the scale of operations and the claims ratio.

\section{Variables Description}

All variables used in the analysis were chosen based on relevant theory and literature. Specifically, the authors have consulted previous studies on the issue, presented in the literature review section, and furthermore, based on the availability of data we wanted to capture various aspects of insurers' performance.

We have adopted the accounting measures as dependent variables since these are important and useful in measuring company performance. Specifically, ROA variable was employed in the model being calculated by dividing a company's after tax annual profits by its total assets multiplied by 100 . Moreover, in order to make the results more robust, additional measure of performance was introduced i.e. ROE being calculated by dividing a company's after tax annual profits by its total equity multiplied by 100 . The authors introduced additional accounting measure of performance with the aim of providing additional evidence on determinants of insurance company's performance.

Taking into account relevant theory and data availability, determinants of insurance profitability are categorised into three groups: a) insurance company - specific factors (size, type, share of reinsurance, combined ratio, age, organizational form); b) structural factors (ownership) and, c) macroeconomic factors (real GDP per capita growth). Explanations related to these variables and the impact of each on the profitability of insurers is detailed below.

Size of a company can be expressed in a number of different ways. As stated by BeckerBlease et al. (2010), in addition to number of employees, total assets and sales are alternative measures of firm size. However, due to the unique features and business activities of insurance companies in relation to other companies, the authors have decided to use gross written premium as the basis for calculating the size of an insurance company following Cummins and Rubio-Misas (2001) approach. This 
variable (In_SIZE) is calculated as a natural logarithm of total gross written premium. The positive relation between firm size and performance is theoretically supported by the economies of scale concept but also by a great number of research (e.g. Lee, 2009; Doğan, 2013). As stated by Cummins and Nini (2002), firm size is expected to be positively related to efficiency if larger firms have lower insolvency risk and/or are able to earn higher revenues because size conveys market power. Moreover, Cummins and Weiss (2004) state that the relatively small firms that once populated the market are unlikely to remain competitive. Furthermore, cost advantages due to scale economies or control over pricing created by market power may enable large firms to achieve unusually high levels of profitability (Robins and Wiersema, 1995). Therefore, we expect positive influence of size variable on profitability.

Type of insurance company variable (TYPE_dummy) is introduced in the model as dummy variable. In some countries, specifically in Croatia, Slovenia and Hungary, insurance companies can conduct exclusively life or exclusively non-life insurance activities, but those insurance companies established prior these provisions came into force can continue providing both life and non-life insurance services. Cummins and Rubio-Misas (2001) studied Spanish insurance market covering both specialists and diversified insurers and introduced dummy variable to distinguish their influence on performance. Therefore, we employed type 1 dummy variable with value 1 referring to insurance companies conducting exclusively life insurance business and 0 otherwise. Type 2 dummy variable with value 1 refers to insurance companies conducting exclusively non-life insurance business and 0 otherwise, while type 3 dummy variable with value 1 refers to composite insurance companies conducting both life and non-life insurance business and 0 otherwise. However, in Poland there are insurance companies active in exclusively life or non-life insurance segment. We expect diversified insurers to outperform specialists.

Since some of the risks that insurers underwrite are too large for them to retain, in order to reduce loss exposures, insurance companies transfer part of the risks to reinsurers. In order to see how premium ceded to reinsurance affects performance, variable calculated as share of premium ceded to reinsurance in total gross written premium multiplied by 100 (RE), was employed in the model. Reinsurance helps insurers to manage their risks by absorbing some of their losses. Reinsurance also stabilises insurance company results and enables growth and innovation to continue. Freeing up capital allows insurers to write more business, thus enabling economic growth and helping to create stability (Swiss Re, 2013). However, since reinsurance involves a certain cost, negative influence of this variable on profitability is expected. Such expectation is proven by research by Burca and Batrînca (2014) and Lee (2014). As stated by Lee (2014) it is consistent with a view that insurers with higher reinsurance dependence tend to have a lower level of firm profitability. It is possible that an insurer that cedes more business to reinsurer and keeps lower retention more or less operates like a reinsurance broker who only transfers risk without underwriting risk and is likely to report less profit for a relatively high percentage of the premium received is ceded to reinsurers. 
Combined ratio (COMB_ratio) variable is calculated as the sum of expense ratio and loss ratio where expense ratio is a ratio of operating expenses to gross written premium while loss ratio represents ratio of claims paid to earned premium. In other words, the combined ratio measures the amount of earned premium that an insurance company must pay to cover the claims and expenses generated by the business. A combined ratio of $100 \%$ means the insurance industry is breaking even on its (net) underwriting business (IAIS, Global Insurance Market Report - GIMAR, 2014). The goal if each insurance company is to increase premiums while at the same time decreasing expenses and losses. Higher values of operating expenses and claims paid have direct impact on insurers' profit, therefore negative influence of this variable is expected. Negative effect of loss ratio was reported in papers by e.g. Öner Kaya (2015) and Malik (2011) while negative influence of expense ratio on profitability was reported by Pervan and Pavic Kramaric (2010).

As stated by Bonin, Hasan and Wachtel (2004) banking sector in transition countries differ from their counterparts in developing countries by the high percentage of assets with majority foreign ownership. Since this holds for insurance sector as well, we have decide to introduce this industry-specific variable in the model as well. Ownership variable $(\mathrm{OWN})$ is employed as dummy variable with 1 indicating foreign owned company (more than $50 \%$ controlled by foreign shareholders) and 0 domesticallycontrolled insurance companies. The additional reason why we have introduced this variable is found in Majumdar (1997) rationale stating that the impact of foreign ownership has to be controlled and a reason why firms invest abroad is that they possess superior capabilities. The possession of these capabilities may lead a firm to display superior performance relative to domestically-controlled firms. This is also proved by Bonin, Hasan and Wachtel (2004) stating that international investors facilitate the transfer of technology and know-how. Furthermore, if foreign owned companies use modern technology from, and rely on the human capital of, their parent companies, they should perform better than domestic companies. Konings (2001) conducted a study finding that the financial performance of companies with foreign capital in Poland is better than the financial performance of companies with domestic capital. Finally, Douma, Rejie and Kabir (2006) state that companies with foreign shareholders presumably have superior access to technical and financial resources. All this leads to our hypothesis that foreign ownership positively influence performance.

Variable age of the insurance company (In_AGE) is measured as the natural logarithm of the number of years since the company's inception following Anderson and Reeb (2003) approach. Regarding the question does age benefit performance the research have produced mixed results. E. g. Majumdar (1997), Loderer and Waechli (2009), Doğan (2013), Akben-Selcuk (2016) found negative influence of firm age on corporate performance supporting the view by Loderer and Waechli (2009) that corporate aging reflects a cementation of organizational rigidities over time. Accordingly, costs rise, growth slows, assets become obsolete, and investment and R\&D activities decline adding that older firms are more likely to have a rigid administrative process and more bureaucracy. Furthermore, Fok, Chang and Lee (2004) state that investment 
opportunities may be limited for firms in the later stages of their life cycles. However, Coad, Segarra and Teruel (2010) support evidence that firms improve with age, finding that ageing firms experience rising levels of productivity, profits, larger size, lower debt ratios, and higher equity ratios. Due to the equivocal findings of the existing research, the expected influence of this variable on performance is ambiguous.

Since our analysis covers both stock insurers and mutuals, organizational form dummy variable (ORG_FORM_dummy) is included in the model to control for organizational form. This approach has been adopted from Cummins, Tennyson and Weiss (1999), Cummins and Rubio-Misas (2001), Cummins and Xie (2008) and Elango, Ma and Pope (2008). A dummy variable equals 1 if an insurer is stock company and zero for mutual. As stated by Cummins and Xie (2008) mutual tend to specialize in lines of insurance that are not too complex or risky and thus provide fewer opportunities for efficiency improvement. Moreover, mutual have more limited access to capital. Furthermore, Cummins and Rubio-Misas (2001) citing Fama and Jensen (1983) hypothesize that mutual managers have less incentive than managers of stock insurers to improve the performance of the firm, because of the more limited mechanisms for managerial discipline and control available in the mutual ownership form. Therefore, we expect mutual to negatively affect performance.

Since we are dealing with cross-country analysis, real GDP per capita growth in a particular country (GDP_per_capita_growth) variable has been introduced in the model. It is a macroeconomic variable, and it is expected to have a positive influence on the insurers' financial performance, since economic growth improves the living standards and the levels of income, increasing the purchasing power of population (Burca and Batrinca, 2014). Therefore, positive effect of this variable on performance measures is expected.

Brief description as well as calculation of each variable used in the model is provided in Table 2.

\section{Table 2 Description of Variables}

\begin{tabular}{|l|l|}
\hline Return on assets (ROA) & $\begin{array}{l}\text { Calculated by dividing a company's after tax annual profits by its total } \\
\text { assets multiplied by } 100 .\end{array}$ \\
\hline Return on equity (ROE) & $\begin{array}{l}\text { Calculated by dividing a company's after tax annual profits by its total } \\
\text { equity multiplied by } 100 .\end{array}$ \\
\hline Size (In_SIZE) & $\begin{array}{l}\text { The variable is calculated as a natural logarithm of total gross written } \\
\text { premium. }\end{array}$ \\
\hline Type (TYPE_dummy) & $\begin{array}{l}\text { Type } 1 \text { dummy variable with value } 1 \text { refers to insurance companies } \\
\text { conducting exclusively life insurance business and } 0 \text { otherwise. } \\
\text { Type } 2 \text { dummy variable with value } 1 \text { refers to insurance companies } \\
\text { conducting exclusively non-life insurance business and } 0 \text { otherwise, }\end{array}$ \\
\hline
\end{tabular}




\begin{tabular}{|l|l|}
\hline & $\begin{array}{l}\text { while type 3 dummy variable with value 1 refers to composite } \\
\text { insurance companies conducting both life and non-life insurance } \\
\text { business and 0 otherwise. }\end{array}$ \\
\hline Share of reinsurance (RE) & $\begin{array}{l}\text { Calculated as share of premium ceded to reinsurance in total gross } \\
\text { written premium. }\end{array}$ \\
\hline Combined ratio (COMB_ratio) & Calculated as the sum of expense ratio and loss ratio. \\
\hline $\begin{array}{l}\text { Ownership (OWN) } \\
\text { Dummy variable with 1 indicates foreign owned company (more than } \\
50 \% \text { controlled by foreign shareholders) and o domestically } \\
\text { controlled insurance companies. }\end{array}$ \\
\hline $\begin{array}{l}\text { Age (In_AGE) } \\
\text { Organizational form } \\
\text { (ORG_FORM_dummy) }\end{array}$ & $\begin{array}{l}\text { A dummy variable that equals } 1 \text { if an insurer is stock company and } \\
\text { zero for mutual. }\end{array}$ \\
\hline $\begin{array}{l}\text { Real GDP per capita growth } \\
\text { (GDP_per_capita_growth) }\end{array}$ & \begin{tabular}{l} 
Macroeconomic variable obtained from Eurostat. \\
\hline
\end{tabular} \\
\hline
\end{tabular}

Source: authors'

\section{Data Sources and Sampling}

Since this research refers to cross-country analysis different sources were used for data collection primarily focusing on regulatory bodies supervising insurance industry in respective country.

In Croatia, dependent variables (ROA, ROE) as well as the explanatory variables, including size based on gross written premium, type of insurance company, share of premium ceded to reinsurance, ownership and age of the insurance company, were calculated using the data manually collected from the annual reports of the insurance companies publicly available through the web pages of the Croatian Financial Agency (FINA). This was also the source for the variable combined ratio for insurance companies that operated in 2010 and for insurance companies that were conducting exclusively life or non-life insurance activities in the period 2011-2013, whereas variable combined ratio was calculated based on the data from financial reports of a particular company.

Data on total gross written premium in Slovenia, necessary for the calculation of variable such as size based on total gross written premium, were taken from the Annual reports of the Slovenian Supervisory Agency (AZN). All other data necessary for calculation of the remaining variables including ROA, ROE, type of insurance company, share of 
premium ceded to reinsurance, combined ratio, ownership structure and number of years operating in the Slovenian market were taken from the extensive individual annual reports available through web pages of the insurance companies.

Data referring to Hungary, particularly data on ROA, ROE, gross written premium, type of insurance company, share of reinsurance and combined ratio were taken directly from or calculated based on data from regular publications of Hungarian Central Bank (MNB) called Golden books. However, data on ownership structure as well as on the age of an insurance company were collected from corporate web pages of a particular insurance company.

Data on Polish insurance market including ROA, ROE, combined ratio and share of premium ceded to reinsurance were taken directly from the Annual Reports published by the Polish Insurance Association (PIU). Based on data on gross written premium size variable was calculated. Moreover, the Insurance Market Yearbook published annually by the Polish Financial Supervision Authority (KNF) was also used as data source. Variables age, type and ownership were also introduced in the model based on the data provided in these publications.

Moreover, data on macroeconomic variable real GDP per capita growth for all countries represented in this analysis were taken from the Eurostat.

The sample covers the entire insurance market in the Republic of Croatia, excluding one reinsurance company. All of these insurance companies are founded and operating as joint stock companies. The number of insurance companies encompassed by the analysis is decreasing over the observed time. This is solely due to the M\&A activities that have occurred in the Croatian insurance market. Basler Insurance Co. as well as the Helios Insurance Co. have exited the market. Specifically, by Decisions of the Commercial Court of 31 May 2013, Helios Insurance Co was acquired by Kvarner Vienna Insurance Group. Moreover, by Decisions of the Commercial Court of 1 September 2014, insurance company Basler Insurance Co. was acquired by Uniqa Insurance Co. and ceased to exist as an independent legal entity. Moreover, three insurance companies (Ergo životno osiguranje d.d., KD životno osiguranje d.d. and Velebit životno osiguranje d.d.) that reported loss after tax as well negative equity in the balance sheet in 2014 were excluded from the further analysis due to falsely positive ROEs. To sum it up, the average number of companies in the each year of the observed period covered by the analysis in the Republic of Croatia amounts to 25,8 .

The initial sample of Slovenian insurance industry consisted of all insurance companies with the headquarters in Slovenia. However, after adjusting for incomplete data, our initial sample consisting of 14 insurance companies was reduced to 11 companies with companies SID, Prva and NLB Vita being excluded from the analysis. However, these three companies accounted for only $1.3 \%$ of the Slovenian insurance market in 2014. The sample covers both joint stock and 1 mutual insurance companies. On average, there were 10.6 insurance companies in Slovenia in the each year of the observed period. 
The Hungarian insurance market covered by the analysis is represented with the all insurance companies (both mutuals and joint stock companies) operating in the market in the period 2010-2014. However, insurance company Magyar Exporthitel Biztosító Zártkörüen Müködő Rt. has not written any premium, therefore, it was omitted from the sample. The average number of companies in the each year of the observed period in Hungary amounts to 33.2 .

The Polish sample consists of all insurance companies both joint stock and mutual that operated in the 2010-2014 period. However, due to the unavailability of data in 2010, 24 insurance companies were omitted from the further analysis. These companies made only $26 \%$ of the total insurance market in 2010. The same is the case in 2011 , when 18 insurance companies, that had total of $22 \%$ market share, were left out. Besides, data unavailability, new entries and exits from the market are the reason why our panel sample is unbalanced. In the each year, the sample of Polish insurance companies consists of 49.4 insurance companies on average.

Due to the facts described above, our final data set is an unbalanced panel due to missing data for some years for some insurance companies. The final sample consists of 137 insurance companies from four countries making a total of 595 observations.

\section{Empirical Analysis and Findings}

For the purpose of econometric data analysis, we employed static unbalanced panel data analysis. Model below forms the basis of our estimation.

$$
\begin{gathered}
Y_{i t}=c+\sum_{k=1}^{K} \beta_{k} X_{i t}^{k}+\varepsilon_{i t} \\
\varepsilon_{i t=Z_{i}}+u_{i t},
\end{gathered}
$$

where:

- $Y_{\text {it }}$ is the profitability of insurance company $i$ at time $t$, with $i=1, \ldots, N ; t=1, \ldots, T$ presented with two different measures of profitability; ROA, ROE. By iterating these profitability measures, we account for two different models depending on the dependent variable used.

- $X_{i t}$ are $\mathrm{k}$ independent variables as discussed above.

$\varepsilon_{i t}$ is the disturbance with $z_{i}$ being the unobserved insurance-specific effect and $u_{i t}$ being the idiosyncratic error. The presented model is a one-way error component regression model where $z_{i} \sim \operatorname{IIN}\left(0, \sigma_{z}^{2}\right)$ and independent of $u_{i t} \sim \operatorname{IIN}\left(0, \sigma_{u}^{2}\right)$.

Before panel analysis was employed, stationarity of each variable was tested. When stationarity of each variable was conducted, problem of multicollinearity between independent variables and the presence of heteroscedasticity was tested as well. But first descriptive statistics for all variables are provided. 
Table 3 shows the descriptive statistics for each variable, based on 595 observations, except for variables RE (share of premium ceded to reinsurance) and In_AGE (natural logarithm of the number of years the insurance company has been present in the market) for which descriptive statistics is based on 591 and 592 observations respectively.

\section{Table 3 Descriptive statistics}

\begin{tabular}{|c|c|c|c|c|c|}
\hline Variable & Obs & Mean & Std. Dev. & Min & Max \\
\hline ROA & 595 & 0.07428 & 8.48808 & -109.74800 & 25.75700 \\
\hline ROE & 595 & 2.99098 & 27.38291 & -330.45830 & 63.03990 \\
\hline In_SIZE & 595 & 13.77668 & 2.77589 & 6.23830 & 20.39660 \\
\hline TYPE_1 & 595 & 0.35966 & 0.48031 & 0 & 1 \\
\hline TYPE_2 & 595 & 0.41176 & 0.49257 & 0 & 1 \\
\hline TYPE_3 & 595 & 0.22857 & 0.42027 & 0 & 1 \\
\hline RE & 591 & 8.41454 & 14.95679 & -0.59580 & 81.80680 \\
\hline COMB_ratio & 595 & 77.78018 & 159.77890 & 0.22000 & 3282.54800 \\
\hline OWN & 595 & 0.66387 & 0.47278 & 0 & 1 \\
\hline In_AGE & 592 & 2.50823 & 0.70734 & 0.00000 & 4.54330 \\
\hline ORG_FORM & 595 & 0.89580 & 0.30578 & 0 & 1 \\
\hline GDP_pc_growth & 595 & 1.38622 & 1.99619 & -2.90000 & 5.00000 \\
\hline
\end{tabular}

Source: authors' calculations

Because the sample in research is unbalanced, stationarity of each variable except dichotomous ones was tested thought Fisher-type unit-root test based on augmented Dickey-Fuller test. Results are shown in Table 4. 


\section{Table 4 Fisher-type unit-root test}

\begin{tabular}{|c|c|c|c|c|c|c|c|c|}
\hline \multirow{2}{*}{ Variables } & \multicolumn{2}{|c|}{ Inverse chi-sqared } & \multicolumn{2}{|c|}{ Inverse normal } & \multicolumn{2}{|c|}{ Inverse logit } & \multicolumn{2}{|c|}{$\begin{array}{l}\text { Modified inv. chi- } \\
\text { squared }\end{array}$} \\
\hline & Statistic & $p$-value & Statistic & $p$-value & Statistic & $p$-value & Statistic & $p$-value \\
\hline ROA & 992.4679 & 0.0000 & -9.3296 & 0.0000 & -20.0513 & 0.0000 & 32.1208 & 0.0000 \\
\hline ROE & 900.7097 & 0.0000 & -8.0676 & 0.0000 & -17.6046 & 0.0000 & 28.0970 & 0.0000 \\
\hline In_SIZE & 760.8456 & 0.0000 & -2.6965 & 0.0035 & -11.3447 & 0.0000 & 21.9635 & 0.0000 \\
\hline RE & 872.9137 & 0.0000 & -6.7684 & 0.0000 & -17.5721 & 0.0000 & 26.8780 & 0.0000 \\
\hline COMB_ratio & 825.5419 & 0.0000 & -7.6394 & 0.0000 & -16.2065 & 0.0000 & 24.8007 & 0.0000 \\
\hline In_AGE & 7571.8717 & 0.0000 & -82.3819 & 0.0000 & -201.7957 & 0.0000 & 321.9752 & 0.0000 \\
\hline GDP pc growth & 354.8935 & 0.0001 & -8.2572 & 0.0000 & -7.7215 & 0.0000 & 4.1614 & 0.0000 \\
\hline
\end{tabular}

Source: authors' calculation

As it can be seen from Table 4 results of Fisher-type unit-root test based on augmented Dickey-Fuller test showed that each variable is stationary at significance level of $1 \%$. After the stationarity of each variable was tested, next step was to test is there a problem of multicollinearity between independent variables.

Using several independent variables in research can lead to misleading and unrealistic valuation of contributions of individual independent variables when trying to explain the dependent variable. This problem can occur when high collinearity exist between two or more independent variables. Multicollinearity can cause unrealistically high standard error estimates of regression coefficients and in the end can cause false conclusion about the significance of independent variables in the model being evaluated. The assumptions that should be followed in research assert that the independent variables are inter-independent. The matrix of Pearson correlation coefficients was computed.

Table 5 shows the results of the research and examines the problem of multicollinearity between the independent variables. 


\section{Table 5 The matrix of Pearson correlation coefficients}

\begin{tabular}{|c|c|c|c|c|c|c|c|c|c|c|}
\hline Variable & $\begin{array}{c}\text { In } \\
\text { size }\end{array}$ & $\begin{array}{c}\text { type } \\
1\end{array}$ & $\begin{array}{c}\text { type } \\
2\end{array}$ & $\begin{array}{c}\text { type } \\
3\end{array}$ & re & $\begin{array}{c}\text { comb } \\
\text { ratio }\end{array}$ & own & $\begin{array}{l}\text { In } \\
\text { age }\end{array}$ & $\begin{array}{l}\text { org } \\
\text { form }\end{array}$ & $\begin{array}{l}\text { gdp pc } \\
\text { growth }\end{array}$ \\
\hline In size & 1.00 & & & & & & & & & \\
\hline type 1 & -0.15 & 1.00 & & & & & & & & \\
\hline type 2 & -0.26 & -0.62 & 1.00 & & & & & & & \\
\hline type 3 & 0.48 & -0.41 & -0.45 & 1.00 & & & & & & \\
\hline re & 0.20 & -0.33 & 0.12 & 0.22 & 1.00 & & & & & \\
\hline $\begin{array}{l}\text { comb } \\
\text { ratio }\end{array}$ & -0.07 & -0.12 & 0.03 & 0.11 & 0.30 & 1.00 & & & & \\
\hline own & 0.05 & 0.11 & -0.26 & 0.18 & -0.05 & -0.10 & 1.00 & & & \\
\hline In age & 0.34 & -0.15 & -0.10 & 0.29 & -0.13 & -0.22 & 0.13 & 1.00 & & \\
\hline org form & 0.14 & 0.05 & -0.20 & 0.18 & 0.03 & 0.00 & 0.32 & -0.12 & 1.00 & \\
\hline $\begin{array}{l}\text { gdp pc } \\
\text { growth }\end{array}$ & -0.01 & 0.17 & 0.09 & -0.30 & -0.16 & -0.17 & 0.10 & 0.13 & -0.13 & 1.00 \\
\hline
\end{tabular}

Source: authors' calculations

An absolute value of the Pearson coefficient higher than 0.7 indicates a strong correlation between independent variables. Table 5 shows that there was no multicollinearity problem between independent variables so none of independent variables was eliminated from the further research.

If the error terms do not have constant variance, they are heteroscedastic. If the heteroscedasticity is present, the standard errors are biased. This can lead to bias in test statistics and confidence intervals. To test the presence of heteroscedasticity Breusch-Pagan test and White's test for heteroscedasticity were employed in research. Results of these tests are given Table 6. 


\section{Table 6 Tests for heteroscedasticity}

\begin{tabular}{lcccc} 
& \multicolumn{2}{c}{ ROA model } & \multicolumn{2}{c}{ ROE model } \\
\cline { 2 - 5 } Tests & chi2 & p-value & chi2 & p-value \\
\hline Breusch-Pagan & 433.10 & 0.0000 & 176.57 & 0.0000 \\
White & 173.70 & 0.0000 & 108.89 & 0.0000 \\
\hline
\end{tabular}

Source: authors' calculations

Results of Breusch-Pagan test and White's test for heteroscedasticity showed that heteroscedasticity was present. Since heteroscedasticity causes standard errors to be biased, after finding proper static panel model, robust standard errors were used in research.

F test, Lagrange Multiplier test and Hausman test were used in order to determine which static panel (pooled panel, static panel with fixed effects or static panel with random effects) would be the most appropriate for research. $\mathrm{F}$ test was applied to analyse the applicability of the panel with fixed effects compared to pooled panel, whereas Lagrange Multiplier test analysed the applicability of panel with random effects compared to static pool panel. Finally, the applicability between models with fixed and random effects was determined using Hausman test. Results of these tests are provided in Table 7.

Table 7 Tests for determination which static panel is the most appropriate

\begin{tabular}{|c|c|c|c|c|c|}
\hline \multirow{2}{*}{ Tests } & & \multicolumn{2}{|c|}{ ROA model } & \multicolumn{2}{|c|}{ ROE model } \\
\hline & & test value & $p$-value & test value & $\mathrm{p}$-value \\
\hline$F$ test & F- statistic & 5.84 & 0.0000 & 3.65 & 0.0000 \\
\hline $\begin{array}{l}\text { Breusch and Pagan } \\
\text { Lagrangian multiplier }\end{array}$ & chi2 & 242.79 & 0.0000 & 125.66 & 0.0000 \\
\hline Hausman test & chi2 & 9.64 & 0.3800 & 8.09 & 0.5250 \\
\hline
\end{tabular}

Source: authors' calculations

Static model with random effects proved to be the most appropriate when analysing the effect on profitability measured with ROA and ROE. F test and Lagrange Multiplier test showed that models with fixed and random effects are more appropriate than pooled model. Since both models were valid, the Hausman test was performed and results showed that model with random effects is more suitable than the model with fixed effects. 
The empirical results for two models, i.e. models with ROA and ROE used as dependent variables, are presented in Table 8, while their interpretation follows afterwards.

\section{Table 8 Parameter estimates of static panel model}

\begin{tabular}{|c|c|c|c|c|c|c|}
\hline \multirow{2}{*}{ Variables } & \multicolumn{3}{|c|}{ ROA model } & \multicolumn{3}{|c|}{ ROE model } \\
\hline & Coef. & Robust Std. Err & $\mathrm{p}$-value & Coef. & Robust Std. Err & $p$-value \\
\hline In_size & 0.0569 & 0.1916 & 0.7660 & 0.0443 & 0.6405 & 0.9450 \\
\hline type_1 & -5.2837 & 5.2816 & 0.3170 & -12.7226 & 15.5935 & 0.4150 \\
\hline type_2 & -6.4391 & 5.3879 & 0.2320 & -17.0817 & 15.9008 & 0.2830 \\
\hline type_3 & -6.1412 & 5.1593 & 0.2340 & -13.4208 & 15.1985 & 0.3770 \\
\hline re & -0.0020 & 0.0563 & 0.9720 & -0.0763 & 0.1567 & 0.6260 \\
\hline com_ratio & 0.0015 & 0.0021 & 0.4760 & 0.0042 & 0.0063 & 0.5030 \\
\hline own & -0.0319 & 1.1634 & 0.9780 & -1.1903 & 3.7943 & 0.7540 \\
\hline In_age & 3.2749 & 0.9255 & 0.0000 & 9.1179 & 2.3918 & 0.0000 \\
\hline org_form & 2.2181 & 2.7651 & 0.4220 & 11.2340 & 7.8475 & 0.1520 \\
\hline gdp_growth & 0.2864 & 0.1851 & 0.1220 & 0.9637 & 0.5503 & 0.0800 \\
\hline _cons & -5.3821 & 7.5608 & 0.4770 & -16.1471 & 21.3097 & 0.4490 \\
\hline Model $p$ value & & 0.0120 & & & 0.0002 & \\
\hline R2 within & & 0.0332 & & & 0.0132 & \\
\hline R2 between & & 0.1232 & & & 0.1537 & \\
\hline R2 overall & & 0.0915 & & & 0.0962 & \\
\hline
\end{tabular}

Source: authors' calculations

Table 8 shows that variable In_AGE (natural logarithm of number of years the insurance company has been operating) is statistically significant at the $1 \%$ level in a model were ROA is used as dependent variable. In other model In_AGE variable is also statistically 
significant at the $1 \%$ level and has positive effects on ROE same as GDP_PC_GROWTH (GDP per capita growth) which is statistically significant at the $10 \%$ level.

The empirical findings suggest that variables that significantly influence performance are age and real GDP per capita growth. Specifically, when ROA is employed as dependent variable, variable age significantly affects performance taking the positive sign. The same pattern is observed in the model with ROE being dependent variable. Furthermore, in latter model real GDP per capita growth also has significant and positive effect on insurance companies' performance. This means that insurance companies that are longer present in the market having longer tradition as well exhibit superior firm performance relative to their counterparts. Such finding, supported by e. g. Coad, Segarra and Teruel (2010), could be explained by the fact, as stated by Öner Kaya (2015), that in connection with the increase in years of operations for the insurance companies that operate in the industry, both their experiences and their reputation in the industry will also increase. Furthermore, Pervan, Curak and Marijanovic (2012) also found positive influence of age on insurance companies' performance explaining it that besides the benefits of learning, older companies have more experience, abilities and skills. They also had enough time to build a good reputation and brand loyalty and can, therefore, enjoy superior performance.

Another finding is that favourable economic situation in terms of real GDP per capita growth creates precondition for superior insurance companies' performance. Furthermore, positive impact of macroeconomic conditions on the profitability of insurance companies indicates that the good shape of the domestic economy is a source of the growth of operations of the real sector and other customers of insurance companies and creates higher demand for new insurance (Kozak, 2011).

\section{Conclusions}

This article investigates the effects of insurance company - specific, insurance industry - specific and macroeconomic factors on profitability measured with ROA and ROE in order to confirm the robustness of the results.

The analysis is conducted using data for all insurance companies that operated in the period 2010 - 2014 in selected Central and Eastern European countries including Croatia, Slovenia, Hungary and Poland.

The results find that In_AGE variable (number of years the insurance company has been conducting business) has significant and positive influence on performance in both ROA and ROE models suggesting that companies that are longer present in the market perform better. Furthermore, macroeconomic variable real GDP per capita growth also significantly and positively affects performance but only in ROE model. Such a finding suggests that favourable macroeconomic conditions are a prerequisite for better insurance performance. Therefore, insurance company-specific and macroeconomic factors are associated with insurance company's profitability. 
However, our study has certain limitations. Specifically, the study covers a specific period (2010-2014). Thus, the results obtained may reflect the characteristics of this period. Therefore, the suggestion for future research might be the extension of the period covered by the analysis provided that available data makes it feasible. Furthermore, since two accounting performance measures were employed in the research, it might be valuable to see the determinants of stock performance measures as well. However, in that case analysis would cover only listed insurance companies. Moreover, extending the sample by covering more countries in the analysis, especially Central and Eastern European countries might be a valuable contribution on the issue. In that way, certain findings could be applied to a larger number of countries, that is, they could bring more general conclusions that would have a greater scientific value.

\section{References}

AKBEN-SELCUK, E. (2016). Does Firm Age Affect Profitability? Evidence from Turkey, International Journal of Economic Sciences Vol. V, No. 3, p. 1-9

ANDERSON, R. C. and REEB, D. M. (2003). Founding-Family Ownership and Firm Performance: Evidence from the S\&P 500, The Journal of Finance, Vol. 58, No. 3, p. 1301-1328, https://www.jstor.org/stable/3094581?seq=1\#page scan tab contents [March 24 ${ }^{\text {th }}$ 2017]

BECKER-BLEASE, J. R.; KAEN, F. R.; ETEBARI, A. and BAUMANN, H. (2010). Employees, firm size and profitability in U.S. manufacturing industries, Investment Management and Financial Innovations, Volume 7, Issue 2, p. 7-23.

BURCA, A. and BATRÎNCA, G. (2014). The Determinants of Financial Performance in the Romanian Insurance Market, International Journal of Academic Research in Accounting, Finance and $\begin{array}{lllll}\text { Management Sciences, } & \text { Vol. } 4, \quad \text { No. } & \text { 299-308, }\end{array}$ http://hrmars.com/hrmars papers/Article 34 The Determinants of Financial Performance.pdf [March 31st 2017]

COAD, A.; SEGARRA, A. and TERUEL, M. (2013). Like milk or wine: Does firm performance improve with age?, Structural Change and Economic Dynamics, Vol. 24, p. 173-189.

Croatian Insurance Bureau, Insurance Market in the Republic of Croatia, 2015, http://www.huo.hr/hrv/statisticka-izviesca/18/publikacije-arhiva/2015 [April 23rd 2017]

CUMMINS, J. D. and NINI, G. P. (2002). Optimal Capital Utilization by Financial Firms: Evidence from the Property-Liability Insurance Industry, Journal of Financial Services Research, Vol. 21, Issue 1, p. 15-53.

CUMMINS, J. D. and RUBIO-MISAS, M. (2001). Deregulation, Consolidation, and Efficiency: Evidence From the Spanish Insurance Industry, Wharton Financial Institutions Center Working Paper No. 02-01, p. 1-52., https://papers.ssrn.com/sol3/papers.cfm?abstract id=294687 [March 23 ${ }^{\text {rd }}$ 2017]

CUMMINS, J. D.; TENNYSON, S. and WEISS, M. A. (1999). Consolidation and efficiency in the US life insurance industry, Journal of Banking \& Finance, Vol. 23, No. 2-4, p. 325-357. 
CUMMINS, J. D. and WEISS, M. A. (2004). Consolidation in the European Insurance Industry: Do Mergers and Acquisitions Create Value for Shareholders?, Wharton The Working Paper Series 0402, https://papers.ssrn.com/sol3/papers.cfm?abstract id=558044 [March 23rd 2017]

CUMMINS, J. D.; WEISS, M. A. and ZI, H. (1999). Organizational form and efficiency: The coexistence of stock and mutual property-liability insurers, Management Science, Vol. 45, No. 9, p. 12541269.

CUMMINS, J. D. and XIE, X. (2008). Mergers and acquisitions in the US property-liability insurance industry: Productivity and efficiency effects, Journal of Banking \& Finance, Vol. 32, p. 30-55, https://www.researchgate.net/profile/J Cummins2/publication/222581473 Mergers Acquisitions in the US Property-

Liability Insurance Industry Productivity and Efficiency Effects/links/57ffb6d708aec3e477eac1 fe.pdf [March 31'st 2017]

DOĞAN, M. (2013). Does Firm Size Affect the Firm Profitability? Evidence from Turkey. Research Journal of Finance and Accounting, Vol. 4, No. 4, p. 53-59, http://www.iiste.org/Journals/index.php/RJFA/article/view/4977 [March 23 ${ }^{\text {rd }}$ 2017]

DOUMA, S.; REJIE, G. and KABIR, R. (2006). Foreign and Domestic Ownership, Business Group and Firm Performance: Evidences from a large emerging market, Strategic Management Journal, Vol. 27, No. 7, p. 637-657.

DOUMPOS, M.; GAGANIS, C. and PASIOURAS, F. (2012). Estimating and explaining the financial performance of property and casualty insurers: A two-stage analysis, The Business and Economics Research Journal, Vol. 5, No. 2, p. 155-170.

ELANGO, B., MA, Y. and POPE, N. (2008). An Investigation into the Diversification: Performance Relationship in the U.S. PropertyLiability Insurance Industry, The Journal of Risk and Insurance, Vol. 75, No. 3, p. 567-591, http://www.jstor.org/stable/pdf/25145296.pdf [April 11 th 2017]

Eurostat, Real GDP per capita, growth rate and totals, http://ec.europa.eu/eurostat/tgm/table.do?tab=table\&init=1\&language $=$ en\&pcode=tsdec100\&plug in=1 [June 6th 2016]

FECHER, F.; KESSLER, D.; PERELMAN, S. and PESTIEAU, P. (1993). Productive performance of the French insurance industry, Journal of Productivity analysis, Vol. 4, No. 1-2, p. 77-93.

FESSUD, Studies in Financial Systems No. 7, Financial System in Poland, 2013.

FOK, R. C. W.; CHANG, Y. and LEE, W. (2004). Bank Relationships and Their Effects on Firm Performance around the Asian Financial Crisis: Evidence from Taiwan, Financial Management, Vol. 33, No. 2, p. 84-112.

Insurance Europe, European insurance industry database, https://www.insuranceeurope.eu/insurancedata [April 3rd 2017]

International Association of Insurance Supervisory - IAIS Global Insurance Market Report - GIMAR 2014, https://www.iaisweb.org/page/supervisory-material/financial-stability-and-macroprudential-policyand-surveillance/global-insurance-market-report-gimar [April 19 ${ }^{\text {th }} 2017$ ] 
International Association of Insurance Supervisory - IAIS, Insurance Core Principles, 2015, file:///C:/Users/Konferencija/Downloads/Insurance Core Principles updated November 2015.p df [April 19th 2017]

KOZAK, S. (2011). Determinants of Profitability of Non-Life Insurance Companies in Poland During Integration with the European Financial System, Electronic Journal of Polish Agricultural Universities, Vol. 14, No. 1, http://www.ejpau.media.pl/articles/volume14/issue1/art-01.pdf [April $6^{\text {th }}$ 2017]

LEE, L. (2009). Does Size Matter in Firm Performance? Evidence from US Public Firms, International Journal of the Economics of Business, Vol. 16, No. 2, p. 189-203, http://www.tandfonline.com/doi/pdf/10.1080/13571510902917400?needAccess=true $\left[\right.$ March $22^{\text {nd }}$ 2017]

LEE, C. (2014). The Effects of Firm Specific Factors and Macroeconomics on Profitability of PropertyLiability Insurance Industry in Taiwan, Asian Economic and Financial Review, Vol. 4, No. 5, p. 681691, http://search.proquest.com/openview/195f0616ab0120efde2cc02bb864321e/1 ?pqorigsite $=$ gscholar \&cbl=1786341 $\left[\right.$ March $31^{\text {st }}$ 2017]

Magyar Nemzeti Bank, Golden Books, https://www.mnb.hu/en/supervision/time-series/golden-books

MAJUMDAR, S. K. (1997). The Impact of Size and Age on Firm-Level Performance: Some Evidence from India, Review of Industrial Organization, Vol. 12, p. 231-241, http://citeseerx.ist.psu.edu/viewdoc/download?doi=10.1.1.942.1529\&rep=rep1\&type=pdf, [March 22 $\left.2^{\text {nd }} 2017\right]$

MALIK, H. (2011). Determinants of Insurance Companies Profitability: An Analysis of Insurance Sector of Pakistan, Academic Research International, Vol. 1, No. 3, p. 315-321, http://lii.com.pk/uploads/4/5/5/7/4557001/inurance companies profitability.pdf [March 31 ${ }^{\text {st }}$ 2017]

ÖNER KAYA, E. (2015). The Effects of Firm-Specific Factors on the Profitability of Non-Life Insurance Companies in Turkey, International Journal of Financial Studies, Vol. 3, p. 510-529, http://www.mdpi.com/2227-7072/3/4/510/htm [March 31 ${ }^{\text {st }}$ 2017]

PERVAN, M. and PAVIC KRAMARIC, T. (2010). Determinants of insurance companies' profitability in Croatia, The Business Review, Cambridge, Vol. 16, No. 1, p. 231-238.

PERVAN, M.; CURAK, M. and MARIJANOVIC, I. (2012). Dynamic Panel Analysis of B\&H Insurance Companies' Profitability, Recent Researches in Business and Economics, p. 158-163, http://www.wseas.us/e-library/conferences/2012/Porto/AEBD/AEBD-24.pdf [April 12 ${ }^{\text {th }}$ 2017]

Polish Insurance Association (PIU), https://piu.org.pl/en/annual-piu-report/

Polish Financial Supervision Authority (KNF),

https://www.knf.gov.pl/en/about the market/Insurance/Financial and statistical data/Annual da $\underline{\text { ta/annual.html }}$

ROBINS, J. and WIERSEMA, M. F. (1995). A Resource-based Approach to the Multibusiness Firm: Empirical Analysis of Portfolio Interletaionships and Corporate Financial Performance, Strategic management Journal, Vol 16, p. 277-299. 
SHIU, Y. (2004). Determinants of United Kingdom general insurance company performance, British Actuarial Journal, Vol. 10, No. 5, p. 1079-1110.

Slovenian Insurance Supervision Agency, https://www.a-zn.si/en/professionals/statistics/

Swiss Re, The essential guide to reinsurance, 2013, http://www.swissre.com/library/107471958.html [March 31 ${ }^{\text {st }}$ 2017]

TIPURIC, D.; PEJIC BACH, M. and PAVIC, T. (2008). Concentration of the insurance industry in selected transition countries of Central and Eastern Europe, 1998-2006, Post-Communist Economies, Vol. 20, Issue 1, p. 97-118. 